\title{
Determination of Trace Elements in Cow Placenta by Tungsten Coil Atomic Emission Spectrometry
}

\author{
Daniel A. Gonçalves ${ }^{1} \cdot$ Ana C. Soncin $^{2} \cdot$ George L. Donati ${ }^{3} \cdot$ Mirian C. dos Santos $^{4}$
}

Received: 22 November 2016 / Accepted: 26 December 2016/Published online: 16 January 2017

(C) Springer Science+Business Media New York 2017

\begin{abstract}
Tungsten coil atomic emission spectrometry (WCAES) is used to determine trace levels of Mn $(403.1 \mathrm{~nm})$ and $\mathrm{Cr}(425.5 \mathrm{~nm})$ in cow placenta. All samples were collected in Ilha Solteira, SP, Brazil. The instrumental setup is based on a tungsten filament extracted from $150 \mathrm{~W}$, $15 \mathrm{~V}$ microscope light bulbs, a solid state power supply, fused silica lens, crossed Czerny-Turner spectrograph, and a thermoelectrically cooled charge-coupled device detector. The limits of detection (LOD) and quantification (LOQ) for $\mathrm{Cr}$ are 2 and $8 \mu \mathrm{g} \mathrm{L}^{-1}$, and 20 and $60 \mu \mathrm{g} \mathrm{L}^{-1}$ for Mn, respectively. Recoveries for $0.30 \mathrm{mg} \mathrm{L}^{-1}$ spikes of each analyte were in the range $93.0-103.0 \%$, and relative standard deviation (RSD) was between 6.50 and $7.20 \%$ for both elements. Placenta samples were microwave-assisted digested with diluted $\mathrm{HNO}_{3}$ and $\mathrm{H}_{2} \mathrm{O}_{2}$ and analyzed by WCAES. The results for $\mathrm{Cr}$ and $\mathrm{Mn}$ were compared with values obtained by tandem inductively coupled plasma mass spectrometry (ICP-MS/ MS). No statistically significant difference was observed between the different methods by applying a paired $t$ test at a 95\% confidence level. The average concentrations of $\mathrm{Cr}$ and
\end{abstract}

Daniel A. Gonçalves

daniel.araujogoncalves@gmail.com

1 Institute of Chemistry, Federal University of Mato Grosso do Sul, Av. Sen. Filinto Muller, 1555, Cidade Universitária, Campo Grande, MS 79074-460, Brazil

2 Department of Physics and Chemistry, UNESP - Univ Estadual Paulista, Av Brasil, 56, Centro, Ilha Solteira, SP 15385-000, Brazil

3 Department of Chemistry, Wake Forest University, Salem Hall, Box 7486, Winston-Salem, NC 27109, USA

4 Department of Analytical Chemistry, UNESP - Univ Estadual Paulista, Rua Prof. Francisco Degni, 55, Quitandinha, Araraquara, SP 14800-060, Brazil
$\mathrm{Mn}$ in the placentas evaluated were $0.95 \pm 0.22$ and $2.64 \pm 0.39 \mu \mathrm{g} \mathrm{g}^{-1}$, respectively. By using a short integration time, LODs for $\mathrm{Cr}$ and $\mathrm{Mn}$ were lower than values reported by recent works using a similar WCAES system.

Keywords Placentome $\cdot$ Cow embryo $\cdot$ Micronutrients · Tungsten atomizer $\cdot$ Trace analysis

\section{Introduction}

The requirements of minerals in cattle (e.g., $\mathrm{Na}, \mathrm{Mg}, \mathrm{K}, \mathrm{Co}, \mathrm{Cr}$, $\mathrm{Mo}, \mathrm{Mn}, \mathrm{S}$, and Se) vary according to the type and level of production, the age, the concentration and the chemical form of the mineral in feeds, and its relations with the other nutrients in the diet during the gestation period, lactation, and confinement $[1,2]$. The cow placenta, as in several animal species, is responsible for respiratory exchanges, storage, and supply of essential nutrients from the mother to the embryo during pregnancy [2-6]. The exchange of nutrients is accomplished by the placentome [7], which is described in the literature as the largest area of contact between the fetus and the mother, with nutrient transport taking place via blood vessels [8].

The essential nutrients responsible for the development of cow embryos are classified in macronutrients (e.g., $\mathrm{Na}, \mathrm{Cl}$, $\mathrm{Mg}, \mathrm{S}$, and $\mathrm{K}$ ) and micronutrients (e.g., $\mathrm{Co}, \mathrm{Cu}, \mathrm{Mo}, \mathrm{Mn}$, $\mathrm{Cr}$, and $\mathrm{Se}$ ), both of which supplied through the food ingested by the mother $[9,10]$. Although present in small amounts, micronutrients are fundamental to the development of important features such as bone structure, and the reproduction and central nervous systems. They are also essential to the function of many important enzymes [11]. Manganese, for example, is essential to the development of the bone structure, liver, pancreas, and many enzymatic processes [12]. The main effects of Mn deficiency on the fetus during pregnancy are 
retarded growth, abnormality of the skeleton, reproductive degeneration, abortions, and abnormalities in the newborn [13]. Chromium is known to have two main functions in cattle: it is involved in glucose tolerance factor (GTF) and as an antistress agent. GTF is the means by which the Cr has an improving effect on insulin binding and increases the number of insulin receptors on the cell surface and sensitivity of $\beta$ cells present in the pancreas. The antistress factor promoted by chromium supplementation reduces the negative effects of stress, which are linked to low immunity. This is mainly due to the increase of cortisol with greater action of the cellular defenses $[13,14]$. This micronutrient is present in natural forage, bran, and grain. However, $\mathrm{Cr}$ content in these food sources is frequently not high enough to meet nutritional requirements, especially considering the elevated metabolism level of these animals in stress conditions such as lactation and periods of pre- and postpartum [14].

Determining the concentrations of micronutrients in placenta may be one of the most effective strategies to better understand the effects of these elements on pregnant cows, their embryos, and the potential long-lasting consequences for the future calf. Despite their importance, limited information can be found in the literature on analytical procedures specific to trace element analysis of bovine placenta. The lack of works describing such applications may be related to the low analyte concentrations and the sample matrix complexity, with potentially severe effects on precision and accuracy [15-17].

The present study seeks to quantify $\mathrm{Cr}$ and $\mathrm{Mn}$ in placenta samples of cow by tungsten coil atomic emission spectrometry (WCAES), and demonstrate the efficiency and simplicity of operation of the WCAES method for complex samples. The first descriptions of the WCAES system were published in 2005 and $2006[18,19]$. Since then, this simple, potentially portable, and sensitive atomic spectrometric method has been successfully applied to a variety of samples and analytes [20-27]. WCAES may represent an interesting alternative to complex and expensive methods such as inductively coupled plasma with optical or mass spectrometry detection (ICP OES and ICP-MS) for applications in trace element analysis of complex samples such as bovine placenta [28]. In this work, six samples of placenta, from cows at different stages of pregnancy, were analyzed by WCAES. The results for $\mathrm{Cr}$ and $\mathrm{Mn}$ were then compared to values determined by tandem ICP-MS (ICP-MS/MS) to evaluate the method's accuracy.

\section{Materials and Methods}

\section{Instrumentation}

Figure 1 shows a schematic representation of the WCAES instrumental setup. A $150 \mathrm{~W}, 15 \mathrm{~V}$ tungsten filament obtained from a microscope light bulb (Osram XENOPHOT 64633 HXL, Pullach, Germany) is used as atomizer. The bulb's glass cover is removed, and its base is kept intact so it can be attached to a conventional two-pronged power socket. The atomizer is kept in a T-shaped borosilicate glass cell (Ace Glass, produto No. D131703, Vineland, Nova Jersey, EUA) to prevent its oxidation during the atomization step, and a gas mixture of $10 \% \mathrm{H}_{2}$ and $90 \%$ Ar flowing at $1.0 \mathrm{~L} \mathrm{~min}^{-1}$ is used as protecting gas [29]. Additional details on the atomization cell configuration can be found in the literature [18-20]. The radiation emitted during atomization was focused through a $25 \mathrm{~mm}$ diameter, $75 \mathrm{~mm}$ focal length, fused silica lens onto the entrance slit of the spectrometer. The 1:1 tungsten atomizer image was projected approximately $1 \mathrm{mn}$ off axis of the slit to improve the signal-to-background ratio $[19,20]$. The spectrometer is composed of a $25-\mu \mathrm{m}$ entrance slit Czerny-Turner monochromator (MonSpec 18, Scientific
Fig. 1 Schematic diagram of the WCAES instrumental setup

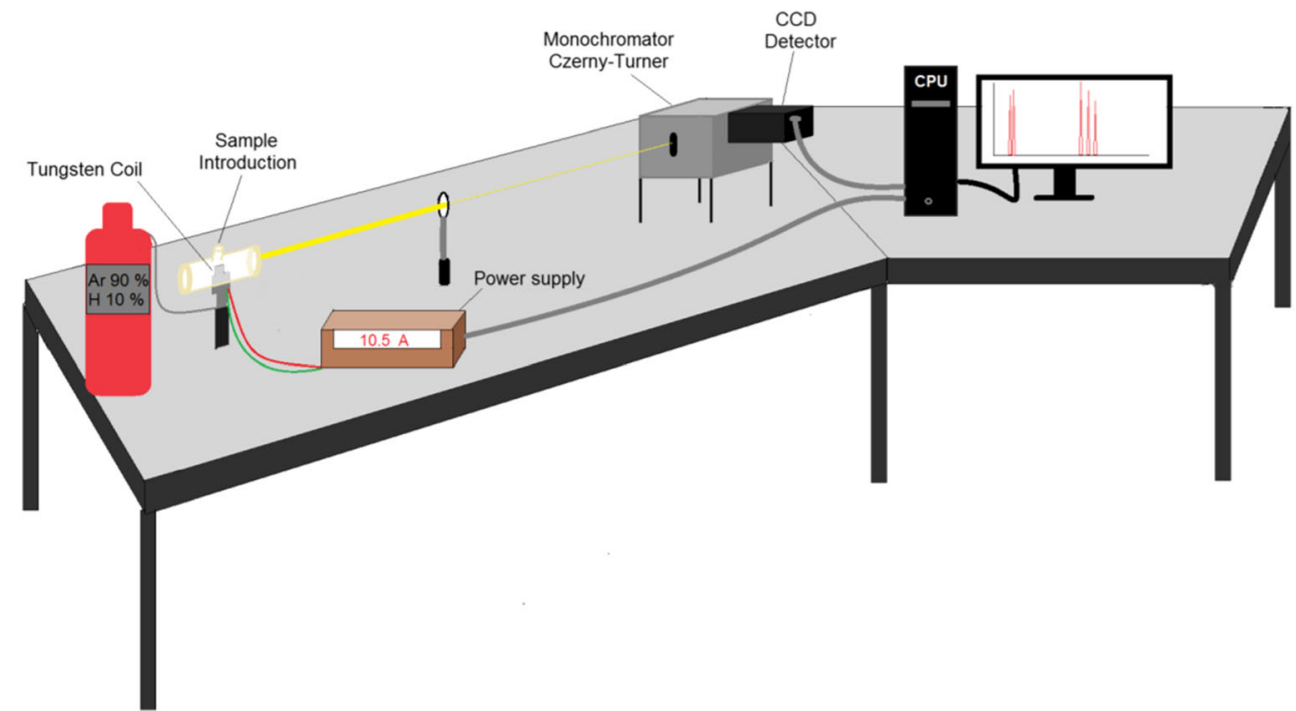


Table 1 Heating program used for digesting the placenta samples

\begin{tabular}{lllll}
\hline Step & Power $(\mathrm{W})$ & Temperature (K) & Time (min) & Pressure (bar) \\
\hline 1 & 100 & 393 & 5 & 75 \\
2 & 600 & 413 & 5 & 75 \\
3 & 1000 & 463 & 10 & 75 \\
4 & 0 & 298 & 15 & 75 \\
\hline
\end{tabular}

Mea-surement Systems Inc., Grand Junction, CO, USA) with a linear dispersion of approximately $2 \mathrm{~nm} / \mathrm{mm}$ at $400 \mathrm{~nm}$, and a charge-coupled device (CCD) detector (Spec-10, Princeton Instruments, Roper Scientific Trenton, NJ, USA). More details on the energy supply, atomizing cell, monochromator, and detector used in this work can be found elsewhere [30].

A tandem ICP-MS (ICP-MS/MS, 8800 triple quadrupole ICP-MS, Agilent Technologies, Japan) equipped with two quadrupoles (Q1 and Q2) and a third generation octopole reaction system $\left(\mathrm{ORS}^{3}\right)$ positioned between Q1 and Q2 were used to evaluate the accuracy of the WCAES method. The ORS $^{3}$ was pressurized with pure oxygen $(\geq 99.999 \%$, Air Products, São Paulo, Brazil) to react with the analytes and promote the formation of oxide species that were monitored at interference-free mass-to-charge ratios $(\mathrm{m} / \mathrm{z})$ by Q2 [31]. The MS/MS mode was used in these determinations, and the main instrument operating conditions were as follows: radio frequency (RF) applied power $1550 \mathrm{~W}$, plasma gas flow rate $18 \mathrm{~L} \mathrm{~min}^{-1}$, auxiliary gas flow $1.8 \mathrm{~L} \mathrm{~min}^{-1}$, carrier gas flow rate $1.09 \mathrm{~L} \mathrm{~min}^{-1}$, sampling depth $8 \mathrm{~mm}$, integration time $3 \mathrm{~s}$, stabilization time $20 \mathrm{~s}$, spray chamber temperature $2{ }^{\circ} \mathrm{C}, \mathrm{O}_{2}$ flow rate in the ORS $3.5 \mathrm{~mL} \mathrm{~min}^{-1}$, Q1 set to monitor $\mathrm{m} / \mathrm{z}$ 52 and 55, and Q2 set to monitor $\mathrm{m} / \mathrm{z} 68$ and 71 for $\mathrm{Cr}$ and $\mathrm{Mn}$, respectively.

The preservation of the samples and preparation for digestion was carried with a freeze-dryer LD 3000 (Terroni Equipamentos Científicos Ltda., São Carlos, SP, Brazil) and a cryogenic mill (SPEX 68000 Freezer/Mil, Metuchen, NJ, USA). Microwave-assisted digestion (MAD) system were carried out employing Anton Paar Multiwave microwave oven (Graz, Austria) equipped with $25 \mathrm{~mL}$ quartz vessels and an Anton Paar Multiwave 3000 microwave oven (Graz, Austria) equipped with $15 \mathrm{~mL}$ PTFE vessels.

Table 2 Heating cycle during the stages of drying, pyrolysis, and atomization for measurements using WCAES

\begin{tabular}{lllll}
\hline Step & Temperature (K) & Time (s) & Process & Signal acquisition \\
\hline 1 & 373 & 85 & Drying & No \\
2 & 1472 & 25 & Pyrolysis & No \\
3 & 298 & 10 & Preatomization & No \\
4 & 3360 & 3 & Atomization & Yes \\
\hline
\end{tabular}

Table 3 Evaluation of the analytical signal integration time $(n=20)$ for $\mathrm{Mn}$ and $\mathrm{Cr}$ using a solution with $0.30 \mathrm{mg} \mathrm{L}^{-1}$ of each analyte

\begin{tabular}{lllll}
\hline Integration time (ms) & $\mathrm{n}^{\circ}$ of spectra & Element & $\mathrm{S} / \mathrm{N}$ ratio & $\mathrm{RSD}$ \\
\hline 10 & \multirow{2}{*}{50} & $\mathrm{Mn}$ & 28 & 4 \\
& & $\mathrm{Cr}$ & 24 & 4 \\
30 & \multirow{2}{*}{35} & $\mathrm{Mn}$ & 36 & 3 \\
& \multirow{2}{*}{20} & $\mathrm{Cr}$ & 25 & 4 \\
50 & & $\mathrm{Mn}$ & 18 & 6 \\
& \multirow{2}{*}{150} & $\mathrm{Cr}$ & 16 & 5 \\
& & $\mathrm{Mn}$ & 14 & 7 \\
& & $\mathrm{Cr}$ & 13 & 8 \\
\hline
\end{tabular}

\section{Reagents and Analytical Solutions}

All solutions were prepared using trace metal grade nitric acid (Fisher, Pittsburgh, PA, USA) and distilled-deionized water (18 M $\Omega \mathrm{cm}$, Milli-Q®, Millipore, Bedford, MA, USA). Single-element stock solutions of $\mathrm{Cr}$ and $\mathrm{Mn}\left(1000 \mathrm{mg} \mathrm{L}^{-1}\right.$, SPEX CertPrep, Metuchen, NJ, USA) were used to prepare the standard reference solutions used for calibration and in spike experiments. The external standard calibration method was used in all determinations. Hydrogen peroxide $30 \% v v^{-1}$ (Acros, Morris Plains, NJ, USA) and trace metal grade nitric acid were used to digest the samples. All the placenta samples were collected in the city of Ilha Solteira, SP, Brazil, under the supervision of a veterinarian. Animals from different regions were chosen to minimize biases due to differences in nutritional conditions.

\section{Sample Preparation}

Placentome samples were drawn of premature placenta from six different cows at different stages of pregnancy. The collection was performed with a scalpel $\mathrm{n}^{\circ} 2$, and the placentomes were stored in polypropylene tubes numbered A1-A6. After collection, samples were kept in a domestic freezer at $268 \mathrm{~K}$. Freeze drying was carried out at $223 \mathrm{~K}$ with hermetic compressor, during $48 \mathrm{~h}$ in a freeze-dryer built in stainless steel AISI 304, with polished sanitary mirrored, forced ventilation, thermal protection, and a drainage system based on ball valve attached to the vacuum pump. In order to ensure the homogeneity of samples and efficiency of the digestion step, the sample was cryogenically ground using a cryogenic. The grinding program was carried out in 2 cycles with 2 min of freezing and 3 min of grinding. Between each cycle, a standby of 2 min was employed.

The powder samples were then subjected to digestion using a MAD system [32, 33]. Sample aliquots of approximately $0.25 \mathrm{~g}$ were digested using $2.5 \mathrm{~mL}$ of $\mathrm{HNO}_{3}, 1.5 \mathrm{~mL}$ of $\mathrm{H}_{2} \mathrm{O}$, and $1.0 \mathrm{~mL} \mathrm{H}_{2} \mathrm{O}_{2}$ in a closed vessel MAD system equipped with a 6-position rotor. The heating program used 
Table 4 Analytical features for WCAES

\begin{tabular}{lll}
\hline & Mn & $\mathrm{Cr}$ \\
\hline Linear equation & $I=1093.9 \mathrm{C}+5.433$ & $I=5289.4 \mathrm{C}+41.193$ \\
Linear dynamic range $\left(\mathrm{mg} \mathrm{L}^{-1}\right)$ & $0.1-1.0$ & $0.1-1.0$ \\
$R^{2}$ & 0.9978 & 0.9957 \\
LOD $\left(\mathrm{mg} \mathrm{L}^{-1}\right)$ & 0.020 & 0.002 \\
\hline
\end{tabular}

for digestion is described in Table 1. The digests were diluted to $25 \mathrm{ml}$ for quantification.

\section{Tungsten Coil Atomic Emission Spectrometry Determinations}

Reference solutions and sample aliquots of $25 \mu \mathrm{L}$ were placed directly on the tungsten atomizer using an automatic micropipette (Eppendorf 5-50 $\mu \mathrm{L}$, Brinkman, Westbury, NY, USA). All solutions were prepared in $1 \% \mathrm{HNO}_{3}$. A solution containing both analytes ( $1.0 \mathrm{mg} \mathrm{L}^{-1}$ each) was used to determine the most efficient WCAES heating program (Table 2). More details on the WCAES heating cycle and the determination of the coil surface temperature can be found in the literature [34, 35]. Different integration times were evaluated to improve sensitivity for $\mathrm{Mn}$ and $\mathrm{Cr}$. Atomic emission signals for $\mathrm{Cr}$ and $\mathrm{Mn}$ were monitored at 425.5 and $403.1 \mathrm{~nm}$, respectively.

\section{Results and Discussion}

\section{Evaluation of Analytical Signal Integration Time}

The main challenges for Mn quantification in WCAES are the relatively low sensitivity and the potential spectral interferences in complex matrix determinations. Strategies such as the application of chemical modifiers to increase signal intensity and minimize spectral interference have been described $[26,36,37]$. A simple alternative, which requires no chemical

Table 5 Summary of the limits of detection obtained in WCAES by several authors

\begin{tabular}{llll}
\hline Element & Conditions & LOD $\left(\mu \mathrm{g} \mathrm{L}^{-1}\right)$ & Ref. \\
\hline $\mathrm{Cr}$ & & 70 & 23 \\
$\mathrm{Cr}$ & Cobalt as chemical modifier & 70 & 38 \\
$\mathrm{Cr}$ & Three emission lines & 4 & 30 \\
$\mathrm{Cr}$ & IL-DLLME & 3 & 27 \\
$\mathrm{Cr}$ & & 2 & This work \\
$\mathrm{Mn}$ & & 900 & 37 \\
$\mathrm{Mn}$ & Three emission lines & 500 & 28 \\
$\mathrm{Mn}$ & Magnesium as chemical modifier & 50 & 37 \\
$\mathrm{Mn}$ & Portable WCAES & 50 & 22 \\
$\mathrm{Mn}$ & & 20 & This work \\
\hline
\end{tabular}

modification, is based on the optimization of the analytical signal integration time to enable temporal separation between the analyte and potential matrix interfering species. For a $500 \mathrm{~ms}$ integration time, limits of detection (LOD) for $\mathrm{Cr}$ and $\mathrm{Mn}$ were calculated as 0.06 and $0.9 \mathrm{mg} \mathrm{L}^{-1}$, respectively, with a linear dynamic range between $1.00-50.0 \mathrm{mg} \mathrm{L}^{-1}$. These values are relatively high when compared with other methods such as GFAAS, MIP OES, ICP OES, and ICP-MS, which can provide LODs at the low $\mu \mathrm{g} \mathrm{L}^{-1}$ level $[32,38-40]$. To improve sensitivity, we have evaluated four different integration times, i.e., $10,30,50$, and $100 \mathrm{~ms}$, using a solution with $0.30 \mathrm{mg} \mathrm{L}^{-1}$ of each $\mathrm{Cr}$ and $\mathrm{Mn}$ and the heating cycle shown in Table 2. Signal-to-noise ratio $(\mathrm{S} / \mathrm{N})$ was used as the evaluating parameter [41], and the results $(n=20)$ are presented in Table 3. As it can be seen, the best $\mathrm{S} / \mathrm{N}$ were observed for a $30 \mathrm{~ms}$ integration time, with values of 25 and 36 , and relative standard deviations (RSD) of 4 and $3 \%$ for $\mathrm{Cr}$ and $\mathrm{Mn}$, respectively.

\section{Analytical Figures of Merit}

The LOD for $\mathrm{Cr}$ and Mn determined by WCAES were calculated according to IUPAC's recommendations as three times the standard deviation of the blank signal $(n=15)$ divided by the calibration curve slope [42]. The blank is a solution of $1 \%$ $\mathrm{HNO}_{3} v v^{-1}$. Similarly, the limits of quantification (LOQ) were calculated as 10 times the standard deviation of the blank signal $(n=15)$ divided by the calibration curve slope. The results are presented in Table 4. As it can be seen for the specific instrument configuration used in this work, the use of a shorter integration time and the optimization of the heating cycle have resulted in a superior analytical performance when compared to recent publications (Table 5). The LODs are adequate for trace element applications using this simple and a potentially portable system.

Table 6 Recovery tests for $\mathrm{Cr}$ and $\mathrm{Mn}$ in premature placenta determined by WCAES (all concentrations are in $\mathrm{m} \mathrm{L} \mathrm{L}^{-1}$ and $n=3$ )

\begin{tabular}{llllll}
\hline Element & Sample & Added & Mean & RSD & Recovery \% \\
\hline Mn & A1 & 0.30 & $0.29 \pm 0.02$ & 7.4 & 97 \\
& A2 & 0.30 & $0.28 \pm 0.02$ & 6.9 & 93 \\
$\mathrm{Cr}$ & A1 & 0.30 & $0.31 \pm 0.02$ & 6.5 & 103 \\
& A2 & 0.30 & $0.28 \pm 0.02$ & 7.2 & 93 \\
\hline
\end{tabular}


Table 7 Comparison of $\mathrm{Mn}$ and Cr determination by WCAES and ICP-MS/MS (all concentrations are in $\mathrm{mg} \mathrm{L}^{-1}$ and $n=3$ )

\begin{tabular}{lllll}
\hline Sample & WCAES & ICP-MS/MS & WCAES & ICP-MS/MS \\
\hline Premature Placenta & Mn & & Cr & \\
A1 & $2.72 \pm 0.34$ & $2.62 \pm 0.07$ & $1.31 \pm 0.48$ & $1.34 \pm 0.14$ \\
A2 & $2.39 \pm 0.23$ & $2.33 \pm 0.06$ & $0.61 \pm 0.16$ & $0.77 \pm 0.01$ \\
A3 & $3.14 \pm 0.19$ & $2.87 \pm 0.07$ & $0.73 \pm 0.10$ & $0.69 \pm 0.01$ \\
A4 & $3.00 \pm 0.63$ & $2.90 \pm 0.09$ & $0.99 \pm 0.23$ & $1.22 \pm 0.05$ \\
A5 & $2.52 \pm 0.55$ & $2.36 \pm 0.16$ & $1.10 \pm 0.20$ & $1.12 \pm 0.13$ \\
A6 & $3.09 \pm 0.50$ & $3.10 \pm 0.03$ & $0.94 \pm 0.14$ & $1.10 \pm 0.03$ \\
\hline
\end{tabular}

\section{Accuracy and Precision}

Spike experiments using two digested samples of placenta (A1 and A2) were carried out to evaluate the method's accuracy. Recoveries for the 1:1 diluted samples spiked with $0.30 \mathrm{mg} \mathrm{L}^{-1}$ of each $\mathrm{Cr}$ and $\mathrm{Mn}$ were in the 93.0-103.0\% range (Table 6). Precisions, represented as \% RSD, were between 6.5 and $7.2 \%$ for both elements.

The WCAES method was applied to all placenta samples, and the results were compared to values obtained by ICP-MS/ MS. The results are shown in Table 7. As it can be seen, no statistically significant difference is observed between the different methods by applying a paired $t$ test at a $95 \%$ confidence level [43].

The dynamic exchange of Mn between gestating cows and embryos, which is essential to the development of the fetus, is well described in the literature [8]. In this study [8], the mother's liver was used as a bioindicator of manganese transfer to the embryo. The results showed that $3.20 \pm 0.19 \mu \mathrm{g} \mathrm{g}^{-1}$ of $\mathrm{Mn}$ present in the mother can result in $0.88 \mu \mathrm{g} \mathrm{g}^{-1}$ of this element available for an adequate formation of the embryo using liver as a bioindicator of manganese. This observation indicates an efficient transport of nutrients via the bloodstream, since the liver has a great effect on the distribution of red blood cells. However, there is no information on $\mathrm{Mn}$ levels in cow placenta. The results presented in the present work show that Mn levels in placenta (an average of $2.64 \pm 0.39 \mu \mathrm{g} \mathrm{g}^{-1}$ ) are similar to values found in the liver of gestating cows [8]. Considering the Mn levels required for the development of a healthy embryo [8], WCAES may represent a simple and effective alternative for the quantification of this element in placenta, with a LOD 44-fold lower than the recommended values.

It has been shown that supplementing cows with $6.25 \mathrm{mg} \mathrm{day}^{-1}$ of $\mathrm{Cr}$ in the first 28 days of the mating season can increase both the percentage of successful pregnancies and milk production [44]. Chromium is involved in many metabolic functions. It activates certain enzymes, stabilizes amino acids and nucleic acids, and may also alter protein synthesis; although, the mechanisms underlying this process are not completely understood. On the other hand, the effect of $\mathrm{Cr}$ on insulin sensitivity has been clearly demonstrated in cattle [45]. Despite its importance, especially in stressful conditions, limited information is available on $\mathrm{Cr}$ levels in pregnant cows. As demonstrated here, an average of $0.95 \pm 0.22 \mu \mathrm{g} \mathrm{g}^{-1} \mathrm{Cr}$ is found in cow placentas.

\section{Conclusions}

Chromium and manganese concentrations in cow placenta are important biomarkers of both cow and embryo health. Determining these elements in such a complex matrix is challenging, and the procedure described here represents a green alternative to more complex techniques. WCAES' low power requirements, as well as low consumption of samples, reagents and gases, are important advantages for the analysis of delicate biological tissue samples such as placenta.

WCAES is an effective method to determine $\mathrm{Cr}$ and $\mathrm{Mn}$ in cow placentas. No chemical modification or preconcentration procedures are required, and a simple external calibration method is sufficient to achieve adequate accuracies and precisions. Matrix effects may be minimized by temporal separation of analytes and interfering concomitants using short integration times. This is a simple, inexpensive, and sensitive method with potential applications in the field.

Acknowledgements The authors would like to thank the Department of Chemistry at Wake Forest University and Agilent Technologies for their support to this work. The fellowship provided to D.A.G. by the Coordenação de Aperfeiçoamento de Pessoal de Nível Superior (CAPES, Brazil, Grant No 99999.002566/2014-01) is also greatly appreciated.

\section{Compliance with Ethical Standards}

Conflict of Interest The authors declare that they have no conflict of interest.

\section{References}

1. Zhou X, Qu X, Zhao S, Wang J, Li S, Zheng N (2015) Analysis of 22 elements in milk, feed, and water of dairy cow, goat, and buffalo 
from different regions of China. Biol Trace Elem Res DOI. doi:10.1007/s12011-016-0819-8

2. Kincaid RL (2011) Assessment of trace mineral status of ruminants: a review. J Anim Sci 77(1-10):2011

3. Tizioto PC, Gromboni CF, Nogueira ARA, De Araujo Nogueira AR, De Souza MM, De Alvarenga MM, Tholon P, Do Nascimento RA, Tullio RR, Medeiros SR, Nassu RT, De Almeida Regitano LC (2014) Calcium and potassium content in beef: influences on tenderness and associations with molecular markers in Nellore cattle. Meat Sci 96:436-440

4. Nriagu J, Boughanen M, Linder A, Howe A, Grant C, Rattray R, Vutchkov M, Lalor G (2009) Levels of As, Cd, Pb, Cu, Se and $\mathrm{Zn}$ in bovine kidneys and livers in Jamaica. Ecotox Environ Safe 72(2): 564-571

5. Rey-Crespo F, Miranda M, López-Alonso M (2013) Essential trace and toxic element concentrations in organic and conventional milk in NW Spain. Food Chem Toxicol 55:513-518

6. Schlafer DH, Fisher PJ, Davies CJ (2000) The bovine placenta before and after birth: placental development and function in health and disease. Anim Reprod Sci 60-61(2):145-160

7. Méndez-Vilas A, Díaz J (2010) Microscopy: science, technology, applications and education, 1st edn. Badajoz, Espanha, p 1039

8. Graham T, Thurmond M, Mohr C, Holmberg C, Anderson M, Keen C (1994) Relationships between maternal and fetal liver copper, iron, manganese, and zinc concentrations and fetal development in California Holstein dairy cows. J Vet Diagn Investig 6:77-87

9. Overton TR, Yasui T (2014) Practical applications of trace minerals for dairy cattle. J Anim Sci 92:416-426

10. Hidiroglou M (1979) Trace element deficiencies and fertility in ruminants: a review. J Dairy Sci 62(8):1195-1206

11. Kumar V (2015) Effect of minerals on dairy animal reproductiona review. Int J Livest Res 5(6):1-10

12. Machado VS, Oikonomou G, Lima SF, Bicalho MLS, Kacar C, Foditsch C, Felippe MJ, Gilbert RO, Bicalho RC (2014) The effect of injectable trace minerals (selenium, copper, zinc, and manganese) on peripheral blood leukocyte activity and serum superoxide dismutase activity of lactating Holstein cows. Vet J 200(2):299-304

13. Bicalho MLS, Lima SF, Ganda EK, Foditsch C, Meira EBS Jr, Machado VS, Teixeira AGV, Oikonomou G, Gilbert RO, Bicalho RC (2014) Effect of trace mineral supplementation on selected minerals, energy metabolites, oxidative stress, and immune parameters and its association with uterine diseases in dairy cattle. J Dairy Sci 97(7):4281-4295

14. Vásquez EFA, Herrera IAPN (2003) Concentração plasmática de cortisol, uréia, cálcio e fósforo em vacas de corte mantidas a pasto suplementadas com levedura de cromo durante a estação de monta. Cienc Rural 33(4):743-747

15. Ceko MJ, Hummitzsch K, Bonner WM, Aitken JB, Spiers KM, Rodgers RJ, Harris HH (2015) Localization of the trace elements iron, zinc and selenium in relation to anatomical structures in bovine ovaries by X-ray fluorescence imaging. Microsc Microanal 21(3):695-705

16. Sheetal SK, Choudhary SK, Sengupta D (2014) Mineral deficiency predisposes occurrence of retention of placenta in crossbred. Vet World 7(12):1140-1143

17. Hostetler C, Kincaid R, Mirando M (2003) The role of essential trace elements in embryonic and fetal development in livestock. Vet J 166(1):125-139

18. Rust JA, Nóbrega JA, Calloway CP Jr, Jones BT (2005) Advances with tungsten coil atomizers: continuum source atomic absorption and emission spectrometry. Spectrochim Acta Part B 60(30):589598

19. Rust JA, Nóbrega JA, Calloway CP Jr, Jones BT (2006) Tungsten coil atomic emission spectrometry. Spectrochim Acta Part B 61(2): 225-229
20. Donati GL, Gu JY, Nobrega JA, Calloway CP Jr, Jones BT (2008) Simulateneous determinations of the lanthanides by tungsten coil emission espectrometry. J Anal At Spectrom 23(3):361-366

21. Gu J, Oliveira SR, Donati GL, Gomes Neto JA, Jones BT (2011) Rugged, portable tungsten coil atomic emission spectrometer. Anal Chem 83(7):2526-2531

22. Santos LN, Donati GL, Calloway CP Jr, Jones BT, Nóbrega JA (2012) Enzymatic proteolysis and in situ digestion as strategies to determine $\mathrm{Cs}$ and $\mathrm{Sr}$ in fish by tungsten coil atomic emission spectrometry. J Anal At Spectrom 27:2082-2087

23. Dancsak SE, Silva SG, Nóbrega JA, Jones BT, Donati GL (2014) Direct determination of sodium, potassium, chromium and vanadium in biodiesel fuel by tungsten coil atomic emission spectrometry. Anal Chim Acta 806(2):85-90

24. Virgilio A, Nobrega JA, Jones BT, Donati GL (2014) Chemical modification in atomic emission: determination of $\mathrm{V}$ in lubricant oils by tungsten coil atomic emission spectrometry. Microchem J 115:58-62

25. Gonzalez MH, Santos LN (2015) Determination of manganese in sludge, alloy, and soil by tungsten coil atomic emission spectrometry. Anal Lett 48:2434-2445

26. Goncalves DA, Jiyan G, dos Santos MC, Jones BT, Donati GL (2015) Direct determination of chromium in empty medicine capsules by tungsten coil atomic emission spectrometry. J Anal At Spectrom 30(6):1395-1399

27. Vidal L, Silva SG, Canals A, Nobrega JA (2016) Tungsten coil atomic emission spectrometry combined with dispersive liquid-liquid microextraction: a synergistic association for chromium determination in water samples. Talanta 148:602-608

28. Donati GL, Jones BT (2011) Development of a novel spectrometric-based temperature probe and the investigation of atomic cloud generation in a tungsten coil atomizer. J Anal At Spectrom 26(4):838-844

29. Donati GL, Kron BE, Jones BT (2009) Simultaneous determination of $\mathrm{Cr}, \mathrm{Ga}, \mathrm{In}$ and $\mathrm{V}$ in soil and water samples by tungsten coil atomic emission spectrometry. Spectrochim Acta Part B 64:559564

30. Donati GL (2011) Trends in tungsten coil atomic spectrometry. 1 ed, ProQuest, Cambridge, p 262

31. Balcaen LEB, Resano FM, Vanhaecke F (2015) Inductively coupled plasma-tandem mass spectrometry (ICP-MS/MS): a powerful and universal tool for the interference-free determination of (ultra)trace elements - a tutorial review. Anal Chim Acta 894:7-19

32. Nóbrega JA, Pirola C, Fialho LL, Rota G, de Campos JCEKMA, Pollo F (2012) Microwave-assisted digestion of organic samples: how simple can it become? Talanta 98:272-276

33. Gonzalez MH, Souza GB, Oliveira RV, Forato LA, Nóbrega JA, Nogueira ARA (2009) Microwave-assisted digestion procedures for biological samples with diluted nitric acid: identification of reaction products. Talanta 79:396-401

34. Donati GL, Callowa CP Jr, Jones BT (2009) Double tungsten coil atomic emission spectrometry: signal enhancement and a new gas phase temperature probe. J Anal At Spectrom 24(8):1105-1110

35. Virgilio A, Healy CK, Nóbrega JA, Jones BT, Donati GL (2013) Evaluation of atomizer conditioning and pyrolysis and atomization temperature control to improve procedures based on tungsten coil atomic emission spectrometry. Microchem J 110:758-763

36. Silva SG, Nobrega JA, Jones BT, Donati GL (2014) Magnesium nitrate as a chemical modifier to improve sensitivity in manganese determination in plant materials by tungsten coil atomic emission spectrometry. J Anal At Spectrom 29:1499-1503

37. Silva SG, Donati GL, Santos LN, Jones BT, Nobrega JA (2013) Cobalt as chemical modifier to improve chromium sensitivity and minimize matrix effects in tungsten coil atomic emission spectrometry. Anal Chim Acta 780:7-12 
38. Junior JBP, Fernandes KG (2011) Studying the distribution of selenium in buffalo and cow's milk whey. J Braz Chem Soc 22(5): 884-890

39. Goncalves DA, McSweeney T, Santos MC, Bradley TJ, George LD (2016) Standard dilution analysis of beverages by microwaveinduced plasma optical emission spectrometry. Anal Chim Acta 909:24-29

40. Aguiar GFM, Batista BL, Rodrigues JL, Luccas PO, Barbosa F Jr (2012) Evaluation of inductively coupled plasma mass spectrometry for determining $\mathrm{Ca}, \mathrm{Cu}, \mathrm{Fe}, \mathrm{Mg}, \mathrm{Mn}, \mathrm{Se}$ and $\mathrm{Zn}$ in bovine semen samples using a simple sample dilution method. J Braz Chem Soc 23(3):573-580

41. Edward V (1997) Comparison of signal-to-noise ratios. Anal Chem 69(2):226-234
42. Long GL, Winefordner JD (1983) Limit of detection a closer look at the IUPAC definition. Anal Chem 55(7):712-724

43. Miller JC, Miller JN (1984) Statistics for analytical chemistry. Ellis Horwood Lt, Chichester, pp 52-56

44. Bryan MA, Socha MT, Tomlinson DJ (2004) Supplementing intensively grazed late-gestation and early-lactation dairy cattle with chromium. J Dairy Sci 87:4269-4277

45. Vargas-Rodriguez CF, Yuan K, Titgemeyer EC, Mamedova LK, Griswold KE, Bradford BJ (2014) Effects of supplemental chromium propionate and rumen-protected amino acids on productivity, diet digestibility, and energy balance of peak-lactation dairy cattle. J Dairy Sci 97(6):3815-3821 